\author{
Aleksandra Stanek \\ Instytut Zarządzania \\ Państwowa Wyższa Szkoła Zawodowa w Oświęcimiu
}

\title{
Kodeks etyczny jako narzędzie zarządzania relacjami z pracownikami
}

Rodowód etyki biznesu jest niewątpliwie filozoficzny, jednak obecnie nie jest to już dziedzina wyłącznie filozoficzna, ale także eklektyczna, ze względu na wykorzystywanie różnych metod badawczych, podstawowe założenia, poziom ogólności przedmiotu badań, kryteria ocen, język itp. Samo pojęcie etyki biznesu można zdefiniować jako: systematyczne studium kwestii moralnych (przekonania, normy, wartości itd.) występujących w biznesie i związanych z nimi zachowań ludzi, organizacji, instytucji (Rok 2004, s. 68).

W ciagu ostatnich 25 lat etyka biznesu stała się samodzielną dyscypliną rozwijającą się przede wszystkim w Stanach Zjednoczonych (Gasparski, Dietl 1997, s. 55). Istotnym czynnikiem wpływającym na rozwój tej dziedziny jest to, że badacze ją reprezentujący zwracają uwagę na cele praktyczne, a nie teoretyczne, konieczne do zrealizowania w firmach.

Jednym z narzędzi do określania i realizowania zasad etycznych w firmie są kodeksy etyczne, które oprócz budowania pozytywnych relacji z otoczeniem zewnętrznym mogą też wzmacniać więzi wewnątrz firmy, pomiędzy pracownikami a pracodawca.

Celem niniejszego artykułu jest udzielenie odpowiedzi na pytania:

- Czy kodeks etyczny może być narzędziem zarządzania relacjami z pracownikami?

- Jakie warunki powinny zostać spełnione, aby stał się takim narzędziem, a nie tylko zbiorem zasad zapisanych na papierze?

Pierwsza część artykułu jest poświęcona zagadnieniu etyki biznesu i jego genezie. Następnie rozważania koncentrują się wokół kodeksów etycznych i ich znaczenia w relacjach firmy z otoczeniem. W kolejnej części zostaną wskazane czynniki wpływające na skuteczność wykorzystywania kodeksów etycznych w procesie zarządzania relacjami z pracownikami.

Opracowanie powstało na podstawie analizy literatury przedmiotu i dotychczasowych badań $\mathrm{w}$ tej materii oraz własnych badań ankietowych autorki, przeprowadzonych w kilku firmach z dużych polskich miast (Kraków, Poznań, Warszawa).

\section{Etyka biznesu - geneza problematyki}

Podejścia do zagadnienia etyki biznesu, jej roli i znaczenia dla przedsiębiorstwa są rozmaite. Wśród współczesnych nurtów etyki biznesu można wskazać za R. Jeurinssenem:

- unitariańską wizję biznesu - która podejmuje próbę odpowiedzi na pytanie, czy można wykorzystać etykę do oceny działalności gospodarczej; zwraca się ku tradycyjnej etyce, postuluje stosowanie zasad, wartości oraz ocen etycznych w gospodarce;

- separatystyczną wizję biznesu - wskazującą biznes jako autonomiczny system rynkowy, niezależny od jakiegokolwiek systemu etycznego. Maksymą tego nurtu jest powiększanie zysków i redukcja kosztów, a twierdzenia moralne są regulowane przez prawo i rynek; 
- wizję integracyjną - głosząca, że gospodarka oparta jest na fundamencie etyki protestanckiej. Podejmuje ona próbę integracji kulturowo-etycznej tradycji z interesem strategicznym. Ważne jest połączenie strategii z etyką. Źródłem tej integracji są etyczne podstawy chrześcijaństwa (Barcik 2000, s. 31).

Różne podejścia można zaobserwować nie tylko w kwestii znaczenia, ale także roli etyki w biznesie. Według E. Sternberg etyka pełni rolę regulującą, czyli jest funkcjonalnym instrumentem kształtowania działalności gospodarczej (Sternberg 1998, s. 32). Etyka powinna więc być narzędziem do tworzenia, ale także kontrolowania działalności biznesowej.

Według P. Pratley zadaniem etyki biznesu jest określenie miejsca biznesu we współczesnym świecie jako większej całości, czyli społeczna fillozofia biznesu (Pratley 1998, s. 75). Etyka służy zatem dopasowaniu biznesu do otaczającej go rzeczywistości.

Zagadnienia etyki biznesu nadal budzą kontrowersje przede wszystkim z powodu relacji pomiędzy deklarowanymi przez firmy zasadami a ich faktycznym działaniem. Najistotniejszy zarzut wobec firm tworzących programy etyczne brzmi: te programy są wprowadzane wyłącznie w celach marketingowych i nie wywołują faktycznych zmian zachowań tych firm na rynku. Zainteresowanie sektora prywatnego problematyką etyki biznesu ma charakter komercyjny - legitymizuje działalność firm w oczach potencjalnych nabywców, przez podkreślenie roli, jaką w tej działalności odgrywa etyka (Barcik 2000, s. 57). Poprzez tworzenie za pomocą programów etycznych wizerunku wysokiego standardu zachowań pracowników w firmie, firmy na rynku oraz firmy w otoczeniu społecznym, w jakim ona działa, firma buduje swój kapitał społeczny i zaufanie (Gasparski, www.cebi.pl, 3.09.2007 r.). Dzięki temu uzyskuje długoterminową przewagę konkurencyjną na rynku.

Przedstawiciele świata nauki i biznesu pozostają zgodni, że problematyki etyki biznesu nie da się pomijać i jest ona coraz bardziej istotna, a przedsiębiorstwa coraz częściej są oceniane poprzez pryzmat działań etycznych.

\section{Kodeksy etyczne i ich znaczenie w relacjach firmy z otoczeniem}

Jednym z najistotniejszych i najbardziej popularnych narzędzi wdrażania zasad etycznych w firmach są kodeksy etyczne: stanowione dla firmy, dla korporacji, a także kodeksy branżowe.

Na początku lat 90. XX w. szacowano, że 22\% największych firm holenderskich dysponowało kodeksem etycznym, podczas gdy we Francji, Niemczech i Wielkiej Brytanii kodeksy takie miało 30-35\% firm, a w Stanach Zjednoczonych - aż 85\% firm. Liczba ta w ciagu dekady wzrosła i nadal się zwiększa. Już w 1995 r. aż 45\% wielkich przedsiębiorstw brytyjskich mogło pochwalić się kodeksem etycznym. W Hongkongu liczącym około 6,5 mln mieszkańców, w 1997 r. liczba organizacji, spółek i firm mających kodeksy wynosiła (według tamtejszego Centrum Rozwoju Etyki) tysiąc jednostek (Gasparski, www.cebi.pl, 4.09.2007 r.).

Wyraźny wzrost zainteresowania tworzeniem kodeksów etycznych wynika z oceny ich wpływu na poprawę relacji firmy z otoczeniem. Londyński Instytut Etyki Biznesu w 2003 r. opublikował wyniki badań przeprowadzonych w firmach w Wielkiej Brytanii, które wykazały, że firmy stosujące kodeksy etyki zawodowej osiagały stosunek zysków do obrotów o 18\% wyższy niż firmy, które nie deklarowały etycznego sposobu prowadzenia biznesu. Jasny system zasad i wartości wyznawanych przez firmę i realizowanych przez jej pracowników wywołuje wzrost zaufania do przedsiębiorstwa także w relacjach handlowych.

Mimo że widać pozytywne skutki wprowadzania kodeksów etycznych, zarówno dla samego przedsiębiorstwa, jak i dla partnerów zewnętrznych, opinie dotyczące ich tworzenia i funkcjonowania są różne. Przeciwnicy kodeksów przestrzegają przed kolejnym sposobem przymuszania 
pracowników do stosowania się do reguł, nakazów i zakazów, co źle wpływa na ich psychikę (Barcik 2000, s. 178). Narzucony przez pracodawcę kodeks zasad i przepisów jest kolejnym ograniczeniem dla pracownika, co nie zachęca do jego stosowania i przestrzegania. Pragmatycy i praktycy zwracają uwagę na cel konstruowania kodeksów i wprowadzania ich w praktykę biznesu: ,same kodyfikatory nie usuną zła, zwłaszcza, gdy zostaną tylko martwą literą na papierze. Istotne jest utrwalanie i programowanie wartości i zasad zawartych w kodeksie, aby jego zapisy były realizowane. Kodeksy są ważnym narzędziem w podnoszeniu, programowaniu i umacnianiu zasad etycznych, dlatego też w ich uchwalaniu powinni brać udział przedstawiciele wszystkich grup pracowniczych" (Barcik 2000, s. 178).

Niezależnie od negatywnych aspektów tworzenia kodeksów etycznych, większość naukowców i biznesmenów pozostaje w zgodzie, że kodeksy etyczne są użyteczne. K.J. Arrow postuluje ich powszechność, ,gdyż poprawiają skuteczność firm w ekonomii, tworzą pozytywny wizerunek firmy na rynku oraz budzą zaufanie wśród interesariuszy" (za: Barcik 2000, s. 180).

Zważywszy na opinie i dylematy dotyczące funkcjonowania kodeksów etycznych, zasadne wydaje się pytanie, jakie zasady i wartości powinny zostać zawarte w kodeksie etycznym, aby spełniał on swoją rolę i nie tylko budował pozytywny wizerunek firmy w otoczeniu, ale także wprowadzał zasady i wartości, które będą realizowane. W wielu kodeksach znajdują się sformułowania bardzo ogólne, a przez to banalne, co do których panuje powszechna zgoda, i nie sa przez nikogo kwestionowane - nie mają zatem siły motywacyjnej (Dietl, Gasparski 1997, s. 61), a tym samym brak mobilizacji do ich przestrzegania.

Racjonalna wydaje się zatem hipoteza, że kodeks etyczny powinien wskazywać podstawowe założenia filozofii i polityki firmy, fundamentalne wartości kultury organizacyjnej, etyczne cele i obowiązki pracownicze (Barcik 2000, s. 179). Powinny się one odnosić przede wszystkim do obszarów, które nie są oczywiste, nie wynikają z kultury czy uniwersalnych zasad i wartości akceptowanych przez społeczeństwo.

Badania przeprowadzone przez brytyjski magazyn „New Consumer” pozwoliły wskazać obszary funkcjonowania firm, w których najczęściej pojawiają się kontrowersje i problemy etyczne (za: Barcik 2000, s.179):

- ujawnianie informacji,

- płaca,

- świadczenia pracownicze,

- warunki pracy,

- demokracja w przedsiębiorstwie,

- równość możliwości,

- zaangażowanie w sprawy społeczności lokalnej,

- środowisko przyrodnicze,

- inne kraje,

- szacunek dla życia,

- zaangażowanie polityczne,

- szacunek dla ludzi,

- polityka marketingowa,

- dostawy dla wojska.

Wydaje się więc istotne, aby, stosownie do specyfiki funkcjonowania danej firmy, w kodeksach etycznych uwzględniane były obszary uważane za kontrowersyjne i budzące wątpliwości pracowników, dotyczące obowiązujących zasad. Problematyka ujęta w kodeksie powinna normować relacje wewnątrz firmy i relacje z interesariuszami zewnętrznymi. Tematykę kodeksów można (za: A. Barcik) podzielić na trzy grupy: 
- zasady normujące stosunki między pracownikami a pracodawcami,

- wytyczne związane z prawami i obowiązkami pracowników,

- zasady etycznego postępowania decydentów wobec grup zewnętrznych.

Wśród zarzutów wobec wprowadzania kodeksów etycznych w firmach pojawia się i ten, że firmy często mają kodeksy, ale pozostają one tylko zapisem na papierze, który nie jest przestrzegany. Istotnym elementem wpływającym na efektywność funkcjonowania kodeksów etycznych oraz postępowanie pracowników w zgodzie z zawartymi w nich zasadami jest sposób ich wdrażania. S.P. Kaptein i H.K. Klamer na podstawie badań przeprowadzonych w Holandii wskazali kilka elementów istotnych przy wdrażaniu kodeksów etycznych:

- motywacja do ich wprowadzenia - korzyści wypływające z ich przyjęcia i stosowania,

- szeroka akceptacja przez pracowników firmy treści i sposobów konstruowania kodeksów,

- praktyczne wdrażanie zasad etycznych kodeksów jako integralnego procesu stosunków społeczno-zawodowych przedsiębiorstwa,

- weryfikacja zasad skonstruowanego kodeksu firmy, ich aprobowanie przez pracowników lub formułowanie nowych wytycznych - nieustanny dyskurs z pracownikami na temat praktycznego stosowania kodeksu,

- zintegrowanie kodeksów etycznych z kulturą i filozofią oraz misją firmy,

- kontrola przestrzegania zasad oraz wprowadzenie sankcji w przypadku rozmijania się z nimi (Barcik 2000, s. 181).

Brytyjski Institute of Business Ethic proponuje dwanaście kroków wprowadzenia kodeksu etycznego w firmie:

1. aprobata - upewnienie się, że kodeks jest aprobowany przez prezesa zarządu i dyrektora zarządzającego;

2. integracja - stworzenie strategii integracji kodeksu z działalnością biznesową w momencie, kiedy został wydany;

3. obieg - wysłanie kodeksu w czytelnej wersji do wszystkich zatrudnionych pracowników oraz przekazywanie go nowym pracownikom;

4. osobista odpowiedź - możliwość wypowiedzenia się w sprawie kodeksu przez wszystkich pracowników; pracodawca powinien wiedzieć, jak zareagować w przypadku różnicy zdań;

5. zatwierdzenie - procedura dla menedżerów, potwierdzająca, że oni i podlegli im pracownicy znają kodeks, wypełniają jego postanowienia i wskazują kwestie nieobjęte kodeksem;

6. kontrakty - warto rozważyć uznanie przestrzegania zasad zawartych w kodeksie za obowiązek poprzez zawarcie odniesień do niego we wszystkich umowach o pracę oraz powiązanie ich przestrzegania z sankcjami dyscyplinarnymi;

7. regularna rewizja - procedura określająca regularną rewizję oraz uaktualnianie kodeksu;

8. egzekwowanie - pracownicy powinni być świadomi konsekwencji nieprzestrzegania kodeksu;

9. szkolenie - zapewnienie, aby osoby odpowiedzialne za szkolenie uwzględniły tematykę zawartą w kodeksie w programach szkoleniowych;

10. tłumaczenie - sprawdzenie, czy kodeks został przetłumaczony do użytku w placówkach zagranicznych oraz innych miejscach, w których język obowiązujący w firmie nie jest językiem podstawowym;

11. dystrybucja - przygotowanie kopii kodeksu dla partnerów biznesowych (dostawców, klientów itp.) i oczekiwanie ich akceptacji w tej materii;

12. raport roczny - przygotowanie kopii kodeksu do rocznego sprawozdania firmy, aby interesariusze oraz opinia publiczna znali zasady etyczne obowiązujące w firmie. 
W obu typologiach bardzo wyraźnie została podkreślona akceptacja pracowników firmy dla zasad zawartych w kodeksie. Istotny wydaje się także zapis dotyczący kontroli przestrzegania kodeksu i sankcji w przypadku jego nieprzestrzegania. Podkreśla on znaczenie kodeksu w firmie, gdzie powinien być uznawany za równie ważny jak inne dokumenty wewnętrzne.

W Polsce od kilku lat obserwuje się aktywność w tworzeniu kodeksów etycznych. Kodeksy powstaja już nie tylko w międzynarodowych korporacjach, ale także w przedsiębiorstwach z sektora MSP, co wskazuje na wzrost znaczenia regulacji etycznych na polskim rynku.

\section{Czynniki poprawiające skuteczność wykorzystywania kodeksów etycznych w procesie zarzą- dzania relacjami z pracownikami - wnioski z badania}

We wcześniejszych wywodach kodeks etyczny został wskazany przede wszystkim jako narzędzie budowania pozytywnych relacji z otoczeniem zewnętrznym. Kodeks etyczny jednak jest także dokumentem wewnętrznym, obowiązującym przepisem firmy określającym zasady wewnętrzne. Powinien być ważnym narzędziem wspierającym zarządzanie relacjami z pracownikami. Jako dokument wewnętrzny, powinien określać zasady etyczne i podstawowe wartości obowiązujące w organizacji.

Ankieta przeprowadzona w kilku polskich firmach pozwoliła wskazać kilka kwestii istotnie wpływających na akceptację kodeksu, a tym samym przestrzeganie i wypełnianie jego zasad. Przeprowadzono ją w dużych firmach (zatrudniających ponad 100 pracowników), wśród pracowników z różnych działów. Brano pod uwagę zarówno firmy posiadające już kodeks etyczny, jak $\mathrm{i}$ takie, które go jeszcze nie mają. Badanie pokazało, że czynnik ten nie ma istotnego wpływu na odpowiedzi respondentów.

\section{Rola kodeksu etycznego wśród dokumentów wewnętrznych firmy}

Kodeks etyczny jest dokumentem wewnętrznym, tworzonym na potrzeby danej firmy i stanowiącym element spisanych $w$ niej zasad i regulacji.

Prawie $60 \%$ pracowników uznało kodeks etyczny za dokument wewnętrzny organizacji równoprawny z innymi dokumentami, których należy przestrzegać, takimi jak regulamin pracy czy instrukcje BHP. Niecałe $10 \%$ sądzi, że jest to dokument mniej istotny. Wynika z tego, że pracownicy uważają zasady etyczne za część norm obowiązujących w firmie, których należy przestrzegać. $70 \%$ pytanych powiedziało, że przestrzeganie kodeksu powinno być standardem i ogólną zasadą postępowania, dlatego też pracowników nie należy nagradzać za przestrzeganie zasad, ale jednocześnie $85 \%$ stwierdziło, że za nieprzestrzeganie kodeksu pracownicy powinni być karani. 77\% pytanych dopuszcza możliwość zwolnienia osoby nieprzestrzegającej zasad kodeksu, gdyż takie zachowanie uważają za brak profesjonalizmu, za niewypełnianie obowiązków pracowniczych. Przestrzeganie zasad utożsamiane jest przez nich z budowaniem marki i pozycji firmy na rynku. Można zatem stwierdzić, że dla samych pracowników kodeks jest wiążącym dokumentem firmy, a to, że nie widzą potrzeby nagradzania za jego przestrzeganie, gdyż powinno ono być działaniem standardowym, wskazuje, że faktycznie traktują go jako zbiór podstawowych i niekwestionowanych zasad obowiązujących w firmie.

\section{Okresowa ocena}

Istotnym elementem zarządzania zasobami ludzkimi jest okresowa ocena działań pracowników (Kożuch 2005, s. 150). 50\% pytanych, w tym $80 \%$ pracowników działu HR, uznało, że ocena postępowania pod względem zgodności z kodeksem etycznym firmy powinna być elementem okresowej oceny pracownika. $33 \%$ pytanych uważa, że taka ocena powinna się odbywać przynajmniej raz w roku. Według 33\% pytanych ocena powinna być dokonywana przez wszystkich 
współpracujących z daną osobą: przełożonego, współpracowników, partnerów zewnętrznych. Jedna czwarta ankietowanych uważa, że oceny powinien dokonywać bezpośredni przełożony oraz współpracownicy.

Zgodność postępowania z kodeksem etycznym powinna zatem być brana pod uwagę przy okresowej ocenie pracownika. Świadomość jej uwzględniania w ocenie ogólnej pracownika powinna wpływać pozytywnie na pogłębianie przez niego znajomości kodeksu oraz przestrzeganie jego zasad. Taka ocena powinna zostać dokonana przez jak najszersze grono osób współpracujących z danym pracownikiem.

\section{Sposób uchwalania kodeksu}

92\% pytanych uważa, że kodeks nie powinien być uchwalany przez sam zarząd, lecz konsultowany z pracownikami. Widać więc, jak istotna dla akceptacji zasad dokumentu jest partycypacja pracowników w jego tworzeniu. Warto także zauważyć, że dla większości pytanych nie jest istotne, czy oni sami biorą udział w tworzeniu dokumentu; byłby on dla nich ważny niezależnie od ich udziału.

Jeśli pracownicy mogą samodzielnie lub poprzez swoich reprezentantów wziąć udział w debacie na temat zasad obowiązujących w firmie, to czują się bardziej zobligowani do ich przestrzegania oraz mocniej związani z zapisami kodeksu.

\section{Forma przedstawiania dokumentu}

Równie istotny jak uchwalanie dokumentu jest sposób przedstawienia jego zawartości tym pracownikom, którzy w jego tworzeniu nie brali udziału, oraz pracownikom nowym. Odpowiedzi ankietowanych wskazuja, jak ważne jest nie tylko zapoznanie się z kodeksem, ale też jego zrozumienie. $60 \%$ pytanych uważa, że formą przedstawienia kodeksu nowym pracownikom powinien być warsztat tłumaczący poszczególne zasady i pozwalający na dyskusję. 33\% pytanych sądzi, że kodeks powinien być przedstawiony w formie prezentacji lub filmu.

Wyniki badań wskazują więc, że samo przekazanie kodeksu pracownikowi do przeczytania nie wystarcza: nie daje możliwości wyjaśnienia wątpliwych kwestii i stwierdzenia, czy pracownik prawidłowo rozumie i interpretuje zapisy kodeksu.

Przedstawienie kodeksu nowemu pracownikowi tylko do przeczytania może skutkować tym, że otrzymując wiele dokumentów do zapoznania się i podpisania, w ogóle o kodeksie zapomni.

\section{Stopień ogólności i ponadczasowość zasad zawartych w kodeksie}

We wcześniejszych wywodach został wskazany problem banalności zasad zawartych w kodeksach etycznych; kodeks zawierający tylko ogólne i znane powszechnie prawdy nie będzie motywować pracowników. Wielu z nich oczekuje, że kodeks będzie regulować istotne i budzące kontrowersje kwestie, które powinny być uaktualniane zależnie od zmieniającego się otoczenia i problemów firmy. Duża grupa pracowników oczekuje jednak, że kodeks będzie zbiorem ponadczasowych zasad, tworzących ramy postępowania pracowników i firmy jako całości.

Połowa respondentów postrzega kodeks stosownie do pierwszego założenia, a połowa - zgodnie z założeniem drugim. Warto jednak zwrócić uwagę, że pracownicy działu HR raczej wskazują opcję elastycznego kodeksu, widząc w niej możliwość stworzenia narzędzia odpowiadającego na aktualne, zmieniające się problemy.

\section{Zasady zawarte w kodeksie a zasady stosowane $w$ życiu prywatnym}

Kluczowym elementem kodeksu wydają się być zapisy, które według pracowników powinny się w nim znajdować. Respondenci wskazują przede wszystkim zasady dotyczące relacji w firmie, ale także zasady funkcjonowania w otoczeniu i współpracy z partnerami - uczciwości wobec 
pracodawcy, klientów, wobec prawa. Dla większości pytanych istotne są też zapisy dotyczące jakości pracy: odpowiedzialności, profesjonalizmu, rzetelności. Zasady te powinny się znaleźć w kodeksie, ponieważ budująjakość i markę firmy. Dla większości pytanych uczciwość, w tym także uczciwość wobec pracodawcy i rzetelne wypełnianie obowiązków, wskazywane były jako najistotniejsze zasady obowiązujące także w życiu prywatnym.

Pracownicy oczekują zapisania w kodeksach tych samych zasad, które są dla nich istotne w życiu codziennym.

\section{Podsumowanie}

Podsumowując, należy uznać, że kodeksy etyczne to istotne źródło i narzędzie do budowania nie tylko pozytywnego wizerunku firmy w otoczeniu, ale także zarządzania relacjami z pracownikami. Kodeks sam w sobie nie jest skutecznym narzędziem budowania postaw i relacji wewnątrz firmy. Decydując się na wprowadzenie kodeksu etycznego i oczekując jego akceptacji i postępowania w zgodzie z nim, kierownictwo firmy powinno mieć na uwadze nie tylko same zapisy w kodeksie, ale także inne czynniki: sposób uchwalania kodeksu i wprowadzenia go w życie, zawarte w nim normy i zapisy oraz ich stopień ogólności. Zasady te w istotny sposób wpływają na odbiór i akceptację kodeksu przez pracowników, a tym samym postępowanie w zgodzie z jego zasadami.

\section{Literatura}

1. Barcik A., 2000, Etyka biznesu w zarzqdzaniu przedsiębiorstwem w polskiej gospodarce rynkowej, Agencja Wydawnicza Trio, Katowice.

2. Etyka biznesu w działaniu. Doświadczenia i perspektywy, 2000, W. Gasparski, J. Dietl (red.), Wydawnictwo Naukowe PWN, Warszawa.

3. Etyka biznesu, 1997, W. Gasparski, J. Dietl (red.), PWN, Warszawa.

4. Klein S., 1995, Business ethics. Reflections from a Platonic point of view, Peter Lang Publishing, New York.

5. Kożuch B., 2005, Podstawy zarzq̨dzania organizacjami, Fundacja Współczesne Zarządzanie, Kraków.

6. Poter M., Kramer M., 2007, Strategia a społeczeństwo. Spoleczna odpowiedzialność biznesu, pożyteczna moda czy nowy element strategii konkurencyjnej?, Harvard Business Review Polska, Warszawa.

7. Pratley P., 1998, Etyka w biznesie. Podstawy zarzadzania, Gebethner i s-ka, Warszawa.

8. Rok B., 2004, Odpowiedzialny biznes w nieodpowiedzialnym świecie, Akademia Rozwoju Filantropii/ Forum Odpowiedzialnego Biznesu, Warszawa.

9. Sternberg E., 1998, Czysty biznes, PWN, Warszawa.

Strony internetowe wykorzystane w pracy:

- Centrum Etyki Biznesu, www.cebi.pl

- Institute of Business Ethics, www.ibe.org.uk 


\section{Code of Conduct as a Tool for Managing the Relations with Employees}

The negative image of business in the public opinion has drawn its attention, firstly in USA, and after that in Europe, to the ethical issues in business activity.

The ethical behaviors of the companies have mostly the external importance - they are the tools to build positive image of the company and trustworthy among its stakeholders: shareholders, customers, public opinion; and therefore they contribute to the economic growth of the company.

Nevertheless, the ethical issues are important also inside the company, in the relations with the employees. Codes of conducts are one of the instruments that besides building the positive relations with the external environment may also strengthen the ties in organization. The way of enacting the code and the employees' identification with the values and rules it contains are important.

The aim of this paper is to answer the questions: May the code of conduct be a tool of managing the relations with employees, and under what conditions may it be a valuable tool, not only another unimportant document?

The first part of the paper focuses on the issue of ethics in business and genesis of this topic. After that, the deliberations focus on codes of conducts and their role in relations with environment. The last part shows the evidences of the efficiency the codes of conducts in managing relations with employees.

Paper is prepared on basis of literature and researches, as well as on the author's surveys in big international companies in some Polish cities (Kraków, Wrocław, Poznań, and Warszawa). 